\title{
REVENUE ANALYSIS OF THE IMPACT OF THE FEE FOR ISSUING A PERMITFORTHE SALE OF ALCOHOL ON THE COMMUNE BUDGET ON THE EXAMPLE OF SELECTED COASTAL COMMUNES
}

\section{Cezary Szydłowski ${ }^{1}$}

Abstract

\begin{abstract}
The article presents an analysis of the level of income flowing to the municipalities' budget from the permit fees to sell alcoholic beverages in selected municipalities. For the purposes of the article, three objectives have been set for determining the level of revenue from the fee. Particular objectives included establishing the share of the revenue from the fee in the total revenue of communes, the dynamics of changes in revenue in particular years and a general assessment of the dynamics of revenue from the fee in communes in relation to the base year. The study for the purpose of publication covered a total of 13 coastal communes ( 8 urban communes and 5 rural communes) from Pomorskie Voivodship in Poland in 2016-2019. The evaluation was carried out on the basis of available reports on the implementation of the commune budget and reports on the revenue of communes. Analytical methods were used.The results of the evaluation indicate that the income from the permit fees to sell alcoholic beverages constitutes a small share in the total income of the examined communes. The highest income from the analysed fee in the study constituted $1.60 \%$ of total income to the commune budget. In the case of most of the surveyed communes, income from the fee did not exceed $1 \%$ of the total income to the commune budget. Moreover, the revenue from the fee in 2016 -2019 in the case of most communes increased annually. The added value of the publication is the presentation of the level of income to the budgets of selected communes from these alcoholic beverage sale fees which enables financing the tasks in this area.
\end{abstract}

JEL classification: H71, H83

Keywords: audit, budget revenues, local tax, public finance, local government, the fee for issuing a permit for the sell alcohol 


\section{INTRODUCTION}

The public finance sector in Poland includes many organisations that carry out their tasks on income from local taxes and fees. These entities also include local government units of the municipal level.

The legal solutions adopted in Poland have given the communal self-governments many tasks which concern various areas of social and economic life. One of the socially important tasks of the commune is to counteract the effects of excessive consumption of alcoholic beverages. The solution in this respect is to grant the local authorities the right to collect taxes and local fees, which will ensure financing of their activities (Stiglitz\&Rosengard, 2015, p. 832).

The catalogue of local taxes and fees collected by municipalities in Poland is extensive and results from legal regulations. One of the levies collected by municipalities in Poland is a fee for issuing and using permits for the sale of alcoholic beverages (Glumińska - Pawlic, 2010, p. 322). The fee in question is collected from business entities conducting retail sale of alcoholic beverages in commercial outlets located in the municipality. The fee is collected by the commune from entrepreneurs at the stage of applying for a permit to sell alcoholic beverages. Subsequently, the fee is collected annually from entities which, on the basis of the permit, sell alcoholic beverages in commercial outlets located in the commune. In accordance with the law, the funds obtained from the above fee must be transferred for the performance of the commune's specific task, which is to carry out activities related to the prevention and resolution of problems resulting from the consumption of alcoholic beverages. Counteracting specific threats to the commune community is a very important task of local authorities. The implementation of the above task is possible by financing it with a fee for using the permit to sell alcoholic beverages. An important specificity of the fee in question is the fact that the funds obtained from it may be spent by communes only for strictly defined purposes.

The issue of evaluating local government revenues from individual taxes and local fees is importantand is the subject of research and analysis by many economists. Therefore, the development of an assessment of the level of income to commune budgets of individual local taxes and charges, together with the determination of the proportion of the levy concerned

in income complements research in this area. Moreover, the analysis of income from the fee may be useful in assessing the process of planning the budget of a given municipality for the following year. The income forecasts are usually prepared on the basis of actual income realisa- tion from individual taxes and fees collected by the municipality in previous years. Preparation of the assessment of income from individual items of income to the budget also enables the preparation of the multiannual financial plan of the municipality (Wołowiec, 2013, pp. 72-82).

In the case of the fee in question, the analysis of income to the commune budget in previous years enables more effective planning of financing of a specific task in the long term. Therefore, the examination of the level of the communes' income from the fee for the sale of alcoholic beverages is an interesting research area both in the scientific field and for its utility for the local community and the commune authorities. The assessment of the level of income from the fee for the sale of alcoholic beverages also provides information about the increase or decrease of its consumption by the inhabitants and tourists visiting of a given commune. Increase in income from the fee for using the permit to sell alcoholic beverages may indicate an increase in the consumption of these goods, which affects the risk of negative social and health effects resulting therefrom.

Conducting an analysis to assess the level of the commune's income from the collection of a charge for alcohol sale is an interesting research issue, especially with regard to the communes located in attractive tourist areas nationwide. Coastal communes in the summer season are visited by tourists in large numbers, which results in an increase in alcoholic beverages sales.

For the purpose of this publication three research objectives have been established. The first objective is to determine the level of the share of revenue to the municipalities' budget from the fee for the permit to sell alcoholic beverages in the total revenue of municipalities in 2016 -2019. The second research objective is to assess the change in the level of revenue from the fee in the revenue of municipalities during the period considered. The last, third objective of the publication is to assess the level of growth or decrease in revenue to the municipal budget from the fee in particular years with reference to the base year 2016. The analysis in the article covers 13 selected communes from Pomorskie Voivodeship in Poland (urban and rural).

The assessment of income from the fee for the sale of alcoholic beverages may be the beginning of an in-depth analysis of subsequent sources of income of municipalities, which may be useful for many potential recipients of this publication.

\section{RESEARCH METHODS}

In the articleanalytical method were used as research methods. The assessment of the level of income of indivi- 
dual communes from the fee for the sale of alcoholic beverages was carried out on the basis of data contained in the reports on the implementation of commune budgets in a given year (for the years 2016-2019) and reports $\mathrm{Rb}-27 \mathrm{~s}$ on the income obtained by the communes in the evaluated year, published in the Public Information Bulletins (on the websites) of the analysed local governments.

For the purposes of the publication, the study included an assessment of the revenue to the municipalities' budgets from the fee for issuing permits for the sale of alcoholic beverages in 13 selected coastal municipalities of the Pomorskie Voivodeship in Poland (8 municipalities: Gdańsk, Gdynia, Jastarnia, Łeba, City of Puck, Sopot, City of Ustka, Władysławowo and 5 rural municipalities: Krokowa, Puck, Smołdzino, Stegna and Ustka). The selection of the communes to be assessed was determined by their coastal location and the availability of financial data for the survey.Additionally, the selection of municipalities for the survey was influenced by the specificity of the seaside seasonality of the increase in the number of tourists, which will be useful for the summer months (June, July, August). In the case of other regions of Poland which are attractive for tourists (mountainous areas), the tourist season is much longer. Moreover, due to its urbanization specificity, Pomorskie Voivodeship is an interesting area for research in the field of evaluating income to the budget of coastal municipalities.

The survey covered the revenue of the communes for 2016-2019. The first stage of the survey was to assess the share of the revenue from the fee for alcohol sales in the total revenue to the budgets of individual communes, the next analysis was to determine the change in the level of revenue from the fee in 2016-2019 (increase or decrease in revenue in a given year). Moreover, the evaluation of the dynamics of the communes' income from the fee for the sale of alcoholic beverages in particular years was also analysed in relation to the base year 2016. The conducted analyses were the basis for presenting a general evaluation of the importance of the income from the fee for the sale of alcoholic beverages in the overall income of the budgets of the analysed communes. For the purpose of the analysis, nominal amounts of revenue in PLN to the budgets of selected 13 communes in 2016-2019 were taken into account. The assessment in the surveyed area may serve as an inspiration for further in-depth analyses with respect to the remaining budgetary revenue of communes.

\section{LITERATURE REVIEW}

Public authorities (government and self-government) are responsible for fulfilling their mission, which should be to play a servant role towards citizens. The tasks of public that a given community is able to satisfy its basic needs, the scope of which depends on the country and the applicable regulations. Implementation of tasks by local authorities should contribute to the economic and social development of a given community (Bahl\& Linn, 1992). Efficient performance of tasks by local government requires decentralisation of public authority by delegating powers and competences to local governments. Decentralisation of public authority also involves granting municipalities the right to impose local public levies. The legal and organisational systems in force in many countries take into account the functioning of central and local taxes. A good example of such solutions is the United States of America, where there are central (federal) taxes collected by the government, and local taxes which are set by local authorities(Gruber, 2016, pp. 13-14). Generally accepted legal solutions around the world indicate that local governments collect various taxes and local fees to ensure the financing of particular tasks of local governments (Bird, 2010).

The statutory opinions of municipalities in Poland are also defined in legal acts regulating many areas of the economy and social life. The activities of local governments, like any public authority, are financed by public levies, which are collected as part of their budgets. Local government in Poland has the right to collect taxes and fees from its residents and economic entities conducting their activities on its territory (Èapková, 1997, pp. 426432). The practical implementation of each task by public bodies requires an adequate source of income to ensure their funding. The income of local governments may take various forms, however, most often it is local taxes and charges(Richard W. Tresch, 2015, pp. 14-15). Polish legal solutions in the field of local taxes and charges enable the authorities to set the rates for selected public levies. The financing of the implementation of tasks by the local government in Poland is based on taxes and fees, a significant part of which is its own revenue. The amount of the share of particular taxes and local fees in income varies and depends on the specific nature of a given commune (Łukomska\&Neneman, 2018, pp. 49-59).

In Poland, the catalogue of public levies collected by the municipality is highly diverse and is regulated by a number of legal regulations, which define the rules for setting their rates and the system for collecting and enforcing the receivables in this respect. Among many local taxes and charges in Poland, there is a fee for using a permit to sell alcoholic beverages at points of sale located in the municipality. The possibility of collecting the fee in question by the commune has been determined by the provisions of the Act on upbringing in sobriety and counteracting alcoholism (Act of 26 October 1982, 1982). The basic objective set out in this Act is to undertake actions 
by the municipal authorities aimed at limiting the consumption of alcoholic beverages and changing the structure of their consumption, initiating and supporting projects aimed at changing customs with regard to the way of consuming these beverages, acting for the sake of sobriety at work, preventing the emergence of and the removal of the consequences of alcohol abuse, as well as support for the activities of social organisations and workplaces in this field (Act of 26 October 1982, 1982, art. 1). The necessity to achieve the above objectives results directly from the increase in alcohol consumption in Poland and worldwide. The World Health Organisation report of 2019 covering 30 European countries clearly indicates a worrying upward trend in alcohol consumption in Poland over several years (Status report on alcohol consumption, harm and policy responses in 30 European countries, 2019). The need to counteract the negative effects of this social problem is the responsibility of public authorities at every level. Public authorities in Poland take various measures to reduce alcohol consumption. Table 1 shows the average alcohol consumption in Poland per capita in years 2010-2018.

Table 1: Average alcohol consumption in Poland per capita in litres of $100 \%$ alcohol in $2010-2018$

\begin{tabular}{|c|c|c|c|c|c|c|c|c|c|}
\hline Years & 2010 & 2011 & 2012 & 2013 & 2014 & 2015 & 2016 & 2017 & 2018 \\
\hline $\begin{array}{c}\text { Average per capita in litres } \\
\text { of } 100 \% \text { alcohol }\end{array}$ & 9.02 & 9.25 & 9.16 & 9.67 & 9.4 & 9.41 & 9.37 & 9.45 & 9.55 \\
\hline
\end{tabular}

Source:http://www.parpa.pl/index.php/badania-i-informacje-statystyczne/statystyki

The above data from Table 1 indicate that alcohol consumption in Poland remains at a similar level exceeding 9 litres of $100 \%$ alcohol with increasing tendency.

An example is the limitation of the number of points of sale of alcoholic beverages and the requirement to have an appropriate permit to sell them. In addition, public authorities in many countries try to reduce consumption by influencing the retail prices of alcoholic beverages. World Health Organisation experts dealing with the impact of excessive alcohol consumption (on human health and its social and economic consequences) emphasise that one effective means of reducing alcohol consumption is a high retail price(Evidence for the effectiveness andcost-effectiveness of interventions to reduce alcohol-related harm, 2009, pp. 76-81). It should be noted, however, that a high price does not always limit the consumption of alcoholic beverages, since countries which have significantly increased the prices of these goods, e.g. through high taxation of these products, have seen an increase in the sale of alcoholic beverages from smuggling or illegal production, which was carried out outside the legal outlets(Ataguba et al., 2017, p. 6).

One of the mentioned ways of reducing the consumption of alcoholic beverages is for public authorities to influence the market mainly in the area of distribution of alcoholic beverages by implementing the need for entrepreneurs to obtain permission to sell alcoholic beverages in a given outlet. The implementation of a system of granting permits for the sale of alcoholic beverages enables the public authorities to regulate in some way the number of outlets in a given area. In addition, the funds collected from the outlets make it possible to raise funds for preventive measures aimed at limiting their consumption by the residents.

Requiring fees for the sale of alcoholic beverages is quite common in many countries. There are many organisational and legal solutions In this respect, however, most often the local authorities have the right to collect tax or fees for issuing permits to sell alcoholic beverages. For example in the United States of America, individual states have the right to collect taxes for licensing the sale of alcoholic beverages, which is implemented in different forms depending on the solutions adopted by local authorities in this respect(Florida Department of Revenue, 2018 \& The Texas Alcoholic Beverage Code, 2019 \&Tennessee Alcoholic Beverages and Beer Tax Guide, 2019). Polish law has imposed on the communes the tasks related to the prevention and solving of alcohol problems and social integration of people addicted to alcohol. The legal regulations in Poland are mainly aimed at limiting the overall 
consumption of alcoholic beverages through measures affecting the price structure of these products. In addition, they should change the structure of consumption of these goods in order to increase the share of sales of lowalcohol drinks (Act of 26 October 1982, 1982, art. 10).

The fulfilment of these tasks by communes requires an appropriate system of financing them. Financial resources accumulated within the budget of a given commune in Poland come both from the commune's own revenues and from the resources provided by the government authorities (Act of 13 November 2003). Ensuring high income for the commune budget is crucial for efficient implementation of its tasks. This requires systemic and efficient management of local commune finances in all areas. This system should take into account the application of appropriate tools and instruments for monitoring the process of collecting local taxes and fees within the scope of the commune's competence (Freire \& Garzón, 2014).

As already mentioned, municipalities in Poland have the right to charge a local fee for the use of a permit to sell alcoholic beverages. The funds obtained by the municipality from the fee may be spent only on the above tasks related to counteracting the effects of alcoholic beverage consumption (Nawrolska, 2017, pp. 291-307). In addition to the right to charge a fee, the municipal authorities have the right to set a maximum number of permits for the sale of alcoholic beverages in its territory. This makes it possible to regulate the number of outlets in the municipality, which contributes to limiting the availability of alcoholic beverages. In addition, communes may also set the rules for the location of the points of sale and serving of alcoholic beverages in the area of the commune, for example by specifying their minimum distance from public facilities such as schools (Act of 26 October 1982, 1982, art. 12).

The issue of the permit is connected with the necessity for the applicant to pay an appropriate fee. The fee for using the permit to sell alcoholic beverages is collected by the commune before it is issued at the stage of applying for the permit by the entrepreneur. The amount of the fee depends on the category of alcoholic beverages to be offered in a given commercial outlet according to the rates specified in the regulations. Three categories of beverages have been identified, resulting from the percentage of their alcohol content. The rates of charges for issuing a permit to sell alcoholic beverages, which are collected by municipalities, are unified for the whole country, the detailed amount of charges depending on the category of alcoholic beverage is presented in Table 2.

Table 2: Rates of payment for the fee for issuing a permit to sell alcohol (applies to entrepreneurs starting their business activity in this respect)

\begin{tabular}{|c|c|}
\hline $\begin{array}{c}\text { Type of the fee for issuing a permit to sell alcohol depending on the } \\
\% \text { alcoholic strength }\end{array}$ & $\begin{array}{c}\text { The applicable fee rates for issuing a permit for } \\
\text { the sale ofalcoholin PLN depending on alcohol } \\
\text { content }\end{array}$ \\
\hline Alcoholic beverages containing up to 4.5\% alcohol and beer & 525 \\
\hline $\begin{array}{r}\text { Alcoholic beverages containing up to 4.5\% to 18\% alcohol (except for } \\
\text { beer). }\end{array}$ & 525 \\
\hline Alcoholic beverages containing more than 18\% alcohol & 2100 \\
\hline $\begin{array}{c}\text { The total fee for issuing a permit for the sell alcoholfrom the three } \\
\text { above categories of alcoholic beverages }\end{array}$ & 3150 \\
\hline
\end{tabular}

Source: Own study based on the Act of 26 October 1982 on Education in Sobriety and Counteracting Alcoholism (i.e. Journal of Laws of 2019, item 2277).

The fees in the amount specified in Table 2 apply to entrepreneurs starting to sell alcoholic beverages in a given outlet. After obtaining the permit, the entrepreneur is obliged to pay the relevant fee annually if he sells alcoholic beverages (Act of 26 October 1982, 1982, art. $11^{1}$ ). The statement of revenue from sales in the previous year presented by the entrepreneur is the basis for the municipality to determine the amount of the fee in a given year. The amount of the fee depends on the value of sales of alcoholic beverages in a given category in the previous year. A detailed breakdown of the fees for operators using the permit to sell alcoholic beverages is presented in Table 3. 
Table 3: Rates of the annual fee for issuing a permit for the sale of alcohol (applies to entrepreneurs starting their business activity in this respect) in the case of exceeding the revenue thresholds specified in the table

\begin{tabular}{|l|l|l|}
\hline \multicolumn{1}{|c|}{ Category of alcoholic beverages sold } & $\begin{array}{c}\text { Thresholds of annual revenue from the } \\
\text { sale of alcoholic beverages in the year } \\
\text { preceding the determination of the } \\
\text { annual fee for issuing a permit for the } \\
\text { sale ofalcoholin PLN }\end{array}$ & $\begin{array}{c}\text { Annual rate of the fee in \% } \\
\text { calculated on the total sales } \\
\text { value of alcolic beverages in } \\
\text { the concerned in the } \\
\text { previous year }\end{array}$ \\
\hline $\begin{array}{l}\text { Alcoholic beverages containing up to } 4.5 \% \text { to } \\
18 \% \text { alcohol (except for beer). }\end{array}$ & 37500 & $1.40 \%$ \\
\hline $\begin{array}{l}\text { Alcoholic beverages containing more than } 4.5 \% \\
\text { to } 18 \% \text { alcohol (except beer) }\end{array}$ & 37500 & $1.40 \%$ \\
\hline $\begin{array}{l}\text { Alcoholic beverages containing more than } 18 \% \\
\text { alcohol }\end{array}$ & & \\
\hline
\end{tabular}

Source: Own study based on the Act of 26 October 1982 on Education in Sobriety and Counteracting Alcoholism (i.e. Journal of Laws of 2019, item 2277)

According to the regulations entrepreneurs whose annual sales value of individual types of alcoholic beverages did not exceed the values specified in Table 3 shall pay a fee in the amount specified in Table 2 (the same as when applying for a permit to sell alcoholic beverages) (Act of 26 October 1982, 1982, art. 11 ${ }^{1}$ ).

There are many risks associated with the issue and collection of fees by municipalities for permits to sell alcoholic beverages. One of them is the threat of potential corruption in issuing permits, especially when the municipal authorities significantly reduce the number of outlets authorised to sell alcoholic beverages. Setting a limit on the number of outlets reduces competition in the distribution of these goods and at the same time constitutes a mechanism for regulating the local market. Counteracting these threats requires the implementation of appropriate control and supervision mechanisms in a commune. The system of internal control and audit is helpful in this respect. The audit and control may, through their independent activities, reveal possible threats and lead to the improvement of the process of issuing permits for the sale of alcoholic beverages and the collection of fees applied by the commune. The implementation of an audit in a given area contributes to closing gaps in the system and increasing the commune's income (Moeller, 2011, pp. 247 -265).

\section{EVALUTION OF MUNICIPALITIES INCOME FROM THE FEE FOR THE PERMIT TO SELL ALCOHOLIC BEVERAGES}

The first stage of the analysis of communes' income from the fee is the assessment of their share in the total income to the commune budget. For the purpose of the analysis, the surveyed municipalities were divided into urban and rural ones. A detailed summary of the results of this assessment is presented in Table 4 (urban municipalities) and Table 5 (rural municipalities).

The share analysis of income to the budget of the 8 surveyed urban communes from the fee, carried out in Table 4, shows that in the years 2016-2019 they constituted a small share in the total income of individual urbancommunes. The highest percentage share of revenue collected from entrepreneurs from the fee for alcohol trade was recorded in Łeba commune in 2017, which amounted to $1.60 \%$ of total revenue to the commune budget. The Łeba commune in particular years 2016-2019 obtained annually revenues from the fee for alcohol trade at a level exceeding $1.50 \%$ of the total income to the budget in a given year $(1.57 \%$ in 2016, 1.60\% in 2017, 1.58\% in 2018 and $1.52 \%$ in 2019 ). 
Only 3 communes (Jastarnia, Łeba, Władysławowo) obtained income from the fee in question at a level exceeding $1 \%$ of the total budget revenue (in 2016-2019).

The level of income from the fee at a level exceeding $1 \%$ of the total budget income was also seen in the city of Ustka, in 2016-2017 (1.08\% in 2016 and 1\% in 2017).

Unfortunately, in the subsequent years 2018-2019, the share of income to the budget of the city of Ustka fell below $1 \%(0.88 \%$ in $2018,0.93 \%$ in 2019$)$.

A downward trend in the share of revenue from the fee for the permit to sell alcohol in total revenue (in percentage terms) has also been noticed in the case of two urban municipalities (Gdynia and Sopot) in 2018-2019. Table 5 shows the fee income of selected rural municipalities.

Table 4: Share of income from the fee for issuing a permit to sell alcohol beverages in the total revenues of the analysed urban municipalities in 2016-2019

\begin{tabular}{|c|c|c|c|c|c|c|c|c|c|}
\hline \multirow{2}{*}{$\begin{array}{l}\text { Name of the mu- } \\
\text { nicipality }\end{array}$} & \multirow{2}{*}{$\begin{array}{l}\text { Municipal } \\
\text { status }\end{array}$} & \multicolumn{4}{|c|}{$\begin{array}{l}\text { Revenue from the fee for issuing a permit to sell } \\
\text { alcoholin } 2016 \text { - } 2019 \text { in PLN }\end{array}$} & \multicolumn{4}{|c|}{$\begin{array}{c}\text { Share in \% of the fee for issuing a } \\
\text { permit to sell alcohol in the total } \\
\text { revenue of the municipalities } 2016 \\
-2019\end{array}$} \\
\hline & & 2016 & 2017 & 2018 & 2019 & 2016 & 2017 & 2018 & 2019 \\
\hline Gdańsk & urban & $\begin{array}{c}11629 \\
027\end{array}$ & 12092360 & 13414613 & $\begin{array}{c}14750 \\
370\end{array}$ & $0.42 \%$ & $0.41 \%$ & $0.41 \%$ & $0.41 \%$ \\
\hline Gdynia & urban & 5487117 & 5656097 & 5852796 & 6142523 & $0.40 \%$ & $0.40 \%$ & $0.36 \%$ & $0.34 \%$ \\
\hline Jastarnia & urban & 308427 & 416636 & 418110 & 416856 & $1.23 \%$ & $1.58 \%$ & $1.51 \%$ & $1.25 \%$ \\
\hline Łeba & urban & 439114 & 466566 & 470998 & 466563 & $1.57 \%$ & $1.60 \%$ & $1.58 \%$ & $1.52 \%$ \\
\hline City of Puck & urban & 371512 & 378286 & 375749 & 425977 & $0.73 \%$ & $0.68 \%$ & $0.61 \%$ & $0.66 \%$ \\
\hline Sopot & urban & 2156622 & 2366286 & 2356206 & 2507701 & $0.72 \%$ & $0.80 \%$ & $0.72 \%$ & $0.66 \%$ \\
\hline City of Ustka & urban & 755598 & 822914 & 811432 & 801961 & $1.08 \%$ & $1.00 \%$ & $0.88 \%$ & $0.93 \%$ \\
\hline Władysławowo & urban & 1286231 & 1396859 & 1333907 & 1416086 & $1.58 \%$ & $1.54 \%$ & $1.35 \%$ & $1.31 \%$ \\
\hline
\end{tabular}

Source: Own study based on reports Rb-27s and reports on the implementation of the commune budget for 2016-2019 published in Public Information Bulletins by local governments 
Table 5: Share of income from the fee for issuing a permit to sell alcohol beverages in the total revenues of the analysed rural municipalities in 2016-2019

\begin{tabular}{|c|c|c|c|c|c|c|c|c|c|}
\hline \multirow{2}{*}{$\begin{array}{l}\text { Name of the mu- } \\
\text { nicipality }\end{array}$} & \multirow{2}{*}{$\begin{array}{l}\text { Munici- } \\
\text { pal sta- } \\
\text { tus }\end{array}$} & \multicolumn{4}{|c|}{$\begin{array}{l}\text { Revenue from the fee for issuing a permit to sell } \\
\text { alcoholin } 2016 \text { - } 2019 \text { in PLN }\end{array}$} & \multicolumn{4}{|c|}{$\begin{array}{l}\text { Share in } \% \text { of the fee for issuing a per- } \\
\text { mit to sell alcohol in the total revenue } \\
\text { of the municipalities } 2016 \text { - } 2019\end{array}$} \\
\hline & & 2016 & 2017 & 2018 & 2019 & 2016 & 2017 & 2018 & 2019 \\
\hline Krokowa & rural & 286458 & 308193 & 311710 & 348817 & $0.49 \%$ & $0.51 \%$ & $0.45 \%$ & $0.51 \%$ \\
\hline $\begin{array}{l}\text { Communes of } \\
\text { Puck }\end{array}$ & rural & 336216 & 368966 & 363510 & 402812 & $0.29 \%$ & $0.30 \%$ & $0.27 \%$ & $0.26 \%$ \\
\hline Smołdzino & rural & 55038 & 54095 & 50020 & 50717 & $0.37 \%$ & $0.34 \%$ & $0.30 \%$ & $0.27 \%$ \\
\hline Stegna & rural & 393277 & 418445 & 421117 & 450496 & $0.91 \%$ & $0.83 \%$ & $0.69 \%$ & $0.86 \%$ \\
\hline $\begin{array}{l}\text { Communes of } \\
\text { Ustka }\end{array}$ & rural & 249337 & 268745 & 268566 & 303233 & $0.51 \%$ & $0.56 \%$ & $0.53 \%$ & $0.50 \%$ \\
\hline
\end{tabular}

Source: Own study based on reports Rb-27s and reports on the implementation of the commune budget for 2016-2019 published in Public Information Bulletins by local governments

The share analysisof income to the budget of the 5 surveyed ruralcommunes from the fee, carried out in Table 5, shows that in the years 2016-2019 they constituted a small share in the total income of individual ruralcommunes.

The smallest percentage share of income from the fee in the total income of the municipality occurred in the rural municipality of Puck. The income of the municipality of Puck from the fee for using the permit to sell alcoholic beverages did not exceed $0.3 \%$ share in total income (0.29\% share in total income in $2016,0.30 \%$ share in total income in 2017, 0.27\% share in 2018 and $0.26 \%$ share in 2019). Such a situation may indicate a downward trend in the share of income from the assessed fee in total income to the Puck Municipality budget. The level of income from the fee may indicate a decrease in the sale of alcoholic beverages in outlets located in the Puck commune.The fall in sales also indicates a potential reduction in alcohol consumption in the municipality.

Generally speaking, it should be stated that the revenue of the surveyed communes (urban and rural) from the fee for using the permit to sell alcoholic beverages by entrepreneurs constituted a small share in the total income of municipalities. Moreover, the share of income from this fee in the total budget income of the communes under analysis was at a similar level in particular years.

In the next Table 6 (urbancommunes) and Table7 (ruralcommunes)there is an analysis of the assessment of the decrease or increase in revenue from the fee for the sale of alcoholic beverages in the surveyed communes in 2016-2019 in PLN. 
Table 6: Changes in revenue from the fee for issuing a permit to sell alcohol beverages in the examined urban communes of the Pomeranian Province in Poland in 2016-2019

\begin{tabular}{|c|c|c|c|c|c|c|c|c|c|c|c|}
\hline \multirow[t]{2}{*}{$\begin{array}{l}\text { Name of the } \\
\text { municipality }\end{array}$} & \multirow{2}{*}{$\begin{array}{l}\text { Muni- } \\
\text { cipal } \\
\text { status }\end{array}$} & \multicolumn{4}{|c|}{$\begin{array}{l}\text { Revenue from the fee for issuing a } \\
\text { permit to sell alcohol beverages be- } \\
\text { tween } 2016 \text { and } 2019\end{array}$} & \multicolumn{3}{|c|}{$\begin{array}{l}\text { Nominal increase/decrease } \\
\text { in fee for issuing a permit } \\
\text { to sell alcohol beverages } \\
\text { income in PLN }\end{array}$} & \multicolumn{3}{|c|}{$\begin{array}{l}\text { Increase/decrease in the } \\
\text { commune's revenue from } \\
\text { the fee for issuing a permit } \\
\text { to sell alcohol beverages in } \\
\%\end{array}$} \\
\hline & & 2016 & 2017 & 2018 & 2019 & $\begin{array}{c}2017 / \\
2016\end{array}$ & $\begin{array}{c}2018 / 2 \\
017\end{array}$ & $\begin{array}{c}2019 / \\
2018\end{array}$ & $\begin{array}{c}2017 / \\
2016\end{array}$ & $\begin{array}{c}2018 / 20 \\
17\end{array}$ & $\begin{array}{c}2019 / 2 \\
018\end{array}$ \\
\hline Gdańsk & urban & $\begin{array}{c}11629 \\
027\end{array}$ & $\begin{array}{c}12092 \\
360\end{array}$ & $\begin{array}{c}13414 \\
613\end{array}$ & $\begin{array}{c}14750 \\
370\end{array}$ & $\begin{array}{l}463 \\
333\end{array}$ & $\begin{array}{c}1322 \\
253\end{array}$ & $\begin{array}{c}1335 \\
757\end{array}$ & $4 \%$ & $11 \%$ & $10 \%$ \\
\hline Gdynia & urban & $\begin{array}{c}5487 \\
117\end{array}$ & $\begin{array}{c}5656 \\
097\end{array}$ & $\begin{array}{c}5852 \\
796\end{array}$ & $\begin{array}{c}6142 \\
523\end{array}$ & $\begin{array}{l}168 \\
980\end{array}$ & 196699 & 289727 & $3 \%$ & $3 \%$ & $5 \%$ \\
\hline Jastarnia & urban & 308427 & 416636 & 418110 & $\begin{array}{l}416 \\
856\end{array}$ & $\begin{array}{l}108 \\
209\end{array}$ & 1474 & -1253 & $35 \%$ & $0.4 \%$ & $-0.3 \%$ \\
\hline Łeba & urban & 439114 & 466566 & 470998 & $\begin{array}{l}466 \\
563\end{array}$ & 27452 & 4432 & -4435 & $6 \%$ & $1 \%$ & $-1 \%$ \\
\hline City of Puck & urban & 371512 & 378286 & 375749 & $\begin{array}{l}425 \\
977\end{array}$ & 6773 & -2536 & 50227 & $2 \%$ & $-1 \%$ & $13 \%$ \\
\hline Sopot & urban & $\begin{array}{c}2156 \\
622\end{array}$ & $\begin{array}{c}2366 \\
286\end{array}$ & $\begin{array}{c}2356 \\
206\end{array}$ & $\begin{array}{c}2507 \\
701\end{array}$ & $\begin{array}{l}209 \\
664\end{array}$ & -10080 & 151495 & $10 \%$ & $-0.4 \%$ & $6 \%$ \\
\hline City of Ustka & urban & 755598 & 822914 & 811432 & $\begin{array}{l}801 \\
961\end{array}$ & 67317 & -11482 & -9471 & $9 \%$ & $-1 \%$ & $-1 \%$ \\
\hline $\begin{array}{l}\text { Władysławo- } \\
\text { wo }\end{array}$ & urban & $\begin{array}{c}1286 \\
231\end{array}$ & $\begin{array}{c}1396 \\
859\end{array}$ & $\begin{array}{c}1333 \\
907\end{array}$ & $\begin{array}{c}1416 \\
086\end{array}$ & $\begin{array}{l}110 \\
628\end{array}$ & -62952 & 82179 & $9 \%$ & $-5 \%$ & $6 \%$ \\
\hline
\end{tabular}

Source: Own study based on reports Rb-27s and reports on the implementation of the commune budget for 2016-2019 published in Public Information Bulletins by local governments 
Table 7: Changes in revenue from the fee for issuing a permit to sell alcohol beverages in the examined rural communes of the Pomeranian Province in Poland in 2016-2019

\begin{tabular}{|c|c|c|c|c|c|c|c|c|c|c|c|}
\hline \multirow[t]{2}{*}{$\begin{array}{l}\text { Name of the } \\
\text { municipality }\end{array}$} & \multirow[t]{2}{*}{$\begin{array}{l}\text { Muni- } \\
\text { cipal } \\
\text { status }\end{array}$} & \multicolumn{4}{|c|}{$\begin{array}{l}\text { Revenue from the fee for issuing a } \\
\text { permit to sell alcohol beverages be- } \\
\text { tween } 2016 \text { and } 2019\end{array}$} & \multicolumn{3}{|c|}{$\begin{array}{l}\text { Nominal increase/ } \\
\text { decrease in fee for issuing } \\
\text { a permit to sell alcohol } \\
\text { beverages income in PLN }\end{array}$} & \multicolumn{3}{|c|}{$\begin{array}{c}\text { Increase/decrease in the } \\
\text { commune's revenue from } \\
\text { the fee for issuing a permit } \\
\text { to sell alcohol beverages in } \\
\%\end{array}$} \\
\hline & & 2016 & 2017 & 2018 & 2019 & $\begin{array}{c}2017 / \\
2016\end{array}$ & $\begin{array}{c}2018 / 2 \\
017\end{array}$ & $\begin{array}{c}2019 / \\
2018\end{array}$ & $\begin{array}{l}2017 / \\
2016\end{array}$ & $\begin{array}{c}2018 / 20 \\
17\end{array}$ & $\begin{array}{c}2019 / 2 \\
018\end{array}$ \\
\hline Krokowa & rural & 286458 & 308193 & 311710 & $\begin{array}{l}348 \\
817\end{array}$ & 21735 & 3517 & 37107 & $8 \%$ & $1 \%$ & $12 \%$ \\
\hline $\begin{array}{l}\text { Communes of } \\
\text { Puck }\end{array}$ & rural & 336216 & 368966 & 363510 & $\begin{array}{l}402 \\
812\end{array}$ & 32749 & -5455 & 39301 & $10 \%$ & $-1 \%$ & $11 \%$ \\
\hline Smołdzino & rural & 55038 & 54095 & 50020 & 50717 & -944 & -4075 & 697 & $-2 \%$ & $-8 \%$ & $1 \%$ \\
\hline Stegna & rural & 393277 & 418445 & 421117 & $\begin{array}{l}450 \\
496\end{array}$ & 25168 & 2672 & 29379 & $6 \%$ & $1 \%$ & $7 \%$ \\
\hline $\begin{array}{l}\text { Communes of } \\
\text { Ustka }\end{array}$ & rural & 249337 & 268745 & 268566 & $\begin{array}{l}303 \\
233\end{array}$ & 19408 & -180 & 34667 & $8 \%$ & $-0,1 \%$ & $13 \%$ \\
\hline
\end{tabular}

Source: Own study based on reports Rb-27s and reports on the implementation of the commune budget for 2016-2019 published in Public Information Bulletins by local governments

Analysis of the change in the level of nominal fee income in PLN from the permit to sell alcoholic beverages to the budget of individual communes in 2016-2019 (on a year-to-year basis) presented in Table 6 indicates that out of the 8 surveyed urban communes only 2 recorded an annual increase in revenue from the fee (Gdańsk, Gdynia). The increase in nominal fee income of these 2 urban municipalities (Gdańsk, Gdynia) was between $4 \%$ and $12 \%$ annually.

At least a one-off decrease in revenue from the fee for the use of the alcohol sales permit in annual terms concerned 6 urban municipalities (Jastarnia, Łeba, City of Puck, Sopot, City of Ustka, Władysławowo).
Nominal highest increase in revenue from the fee among the 8 surveyed urban municipalities in the PLN of alcoholic beverages sales permit was noted by thecommunes of Puck (an increase in revenue by PLN 39.301) in 2019 compared with revenue from this fee in 2018 .

Nominal drops in PLN income from the fee in two consecutive years (on an annual basis) were recorded by two rural municipalities (Smołdzino municipality in 20172018 compared to the previous year and the city of Ustka in 2018-2019 compared to the previous year).

Table 8 presents the dynamics of fee income in the period under consideration in relation to the base year 2016 in urban municipalities. 
Table 8: The dynamics of income from the fee for issuing a permit to sell alcohol beverages in 2016-2019 to the budgets of the surveyed urban municipalities

\begin{tabular}{|c|c|c|c|c|c|c|c|c|}
\hline \multirow[t]{2}{*}{$\begin{array}{l}\text { Name of the muni- } \\
\text { cipality }\end{array}$} & \multirow[t]{2}{*}{$\begin{array}{l}\text { Municipal } \\
\text { status }\end{array}$} & \multicolumn{4}{|c|}{$\begin{array}{l}\text { Revenue from the fee for issuing a permit to sell } \\
\text { alcohol beverages between } 2016 \text { and } 2019\end{array}$} & \multicolumn{3}{|c|}{$\begin{array}{c}\text { Dynamics of revenue from the fee } \\
\text { for issuing a permit to sell alcohol } \\
\text { beverages in } 2016-2019 \\
(2016=100 \%)\end{array}$} \\
\hline & & 2016 & 2017 & 2018 & 2019 & $\begin{array}{c}2017 / 201 \\
6\end{array}$ & $\begin{array}{l}2018 / 201 \\
6\end{array}$ & $\begin{array}{c}2019 / 201 \\
6\end{array}$ \\
\hline Gdańsk & urban & $\begin{array}{c}11629 \\
027 \\
\end{array}$ & $\begin{array}{c}12092 \\
360 \\
\end{array}$ & $\begin{array}{c}13414 \\
613 \\
\end{array}$ & $\begin{array}{c}14750 \\
370 \\
\end{array}$ & $4 \%$ & $15 \%$ & $27 \%$ \\
\hline Gdynia & urban & 5487117 & 5656097 & 5852796 & 6142523 & $3 \%$ & $7 \%$ & $12 \%$ \\
\hline Jastarnia & urban & 308427 & 416636 & 418110 & 416856 & $35 \%$ & $36 \%$ & $35 \%$ \\
\hline Łeba & urban & 439114 & 466566 & 470998 & 466563 & $6 \%$ & $7 \%$ & $6 \%$ \\
\hline City of Puck & urban & 371512 & 378286 & 375749 & 425977 & $2 \%$ & $1 \%$ & $15 \%$ \\
\hline Sopot & urban & 2156622 & 2366286 & 2356206 & 2507701 & $10 \%$ & $9 \%$ & $16 \%$ \\
\hline City of Ustka & urban & 755598 & 822914 & 811432 & 801961 & $9 \%$ & $7 \%$ & $6 \%$ \\
\hline Władysławowo & urban & 1286231 & 1396859 & 1333907 & 1416086 & $9 \%$ & $4 \%$ & $10 \%$ \\
\hline
\end{tabular}

Source: Own study based on reports Rb-27s and reports on the implementation of the commune budget for 2016-2019 published in Public Information Bulletins by local governments

Table 9: The dynamics of income from the fee for issuing a permit to sell alcohol beverages in 2016-2019 to the budgets of the surveyed rural municipalities

\begin{tabular}{|c|c|c|c|c|c|c|c|c|}
\hline \multirow[t]{2}{*}{$\begin{array}{l}\text { Name of the muni- } \\
\text { cipality }\end{array}$} & \multirow[t]{2}{*}{$\begin{array}{l}\text { Municipal } \\
\text { status }\end{array}$} & \multicolumn{4}{|c|}{$\begin{array}{l}\text { Revenue from the fee for issuing a permit to sell } \\
\text { alcohol beverages between } 2016 \text { and } 2019\end{array}$} & \multicolumn{3}{|c|}{$\begin{array}{l}\text { Dynamics of revenue from the fee } \\
\text { for issuing a permit to sell alcohol I } \\
\text { beverages in 2016-2019 } \\
\text { (2016=100\%) }\end{array}$} \\
\hline & & 2016 & 2017 & 2018 & 2019 & $\begin{array}{l}2017 / 201 \\
6\end{array}$ & $\begin{array}{c}2018 / 201 \\
6\end{array}$ & $\begin{array}{l}2019 / 201 \\
6\end{array}$ \\
\hline Krokowa & rural & 286458 & 308193 & 311710 & 348817 & $8 \%$ & $9 \%$ & $22 \%$ \\
\hline Communes of Puck & rural & 336216 & 368966 & 363510 & 402812 & $10 \%$ & $8 \%$ & $20 \%$ \\
\hline Smołdzino & rural & 55038 & 54095 & 50020 & 50717 & $-2 \%$ & $-9 \%$ & $-8 \%$ \\
\hline Stegna & rural & 393277 & 418445 & 421117 & 450496 & $6 \%$ & $7 \%$ & $15 \%$ \\
\hline $\begin{array}{l}\text { Communes of Ust- } \\
\text { ka }\end{array}$ & rural & 249337 & 268745 & 268566 & 303233 & $8 \%$ & $8 \%$ & $22 \%$ \\
\hline
\end{tabular}

Source: Own study based on reports Rb-27s and reports on the implementation of the commune budget for 2016-2019 published in Public Information Bulletins by local governments 
The comparison of the dynamics of changes in the level of nominal revenue from the alcohol sales permit fee to the budgets of the evaluated urban municipalities in PLN in 2017-2019 in relation to the base year 2016 presented in Table 8 indicates an increase in each municipality. The largest annual income increases (in 2017-2019) in relation to 2016 occurred in Jastarnia. Depending on the year, this increase was in the range of $35 \%-36 \%$ of income (compared to the income in 2016). It is worth noting that in 2019 a total of 2 communes recorded an increase in revenue from the fee for the use of alcohol sales permit at a level exceeding $20 \%$ compared to the revenue obtained from this fee in the base year 2016 (Gdańsk increased by $27 \%$, Jastarnia increased by $35 \%$ ).

Table 9 presents the dynamics of fee income in the period under consideration in relation to the base year 2016 in rural municipalities.

The comparison of the dynamics of changes in the level of nominal revenue from the abatement to the budgets in PLN of individual rural communes in 2017-2019 in relation to the base year 2016 presented in Table 9 shows that the decrease in revenue from the fee for using the permit to sell alcoholic beverages concerned only theSmołdzino commune. The Smołdzino commune is the only one of the 5 rural communes in which, in 2017-2019, the revenue from the analysed fee decreased compared to the base year 2016 (the drop in revenue was 2\%-9\% depending on the year). The other municipalities in particular years recorded an increase in income compared to the base year 2016. In total, in 2019, the 3 rural communes surveyed recorded an increase in revenue from the fee for using the alcohol sales permit, compared to the base year 2016, at a level exceeding 20\% (Krokowa, Stegna, Ustka).

The funds raised by the municipalities from the fee must be used for the prevention and solving of alcohol problems and social integration of people addicted to alcohol, i.e:

1) increasing the availability of therapeutic and rehabilitation assistance for alcoholics;

2) providing families with alcohol-related problems with psychosocial and legal assistance, and in particular protection against domestic violence;

3) conducting prophylactic information and educational activities in the field of solving alcohol problems, in particular for children and young people, including conducting extracurricular sports activities, as well as activities aimed at feeding children participating in extracurricular care, educational and sociotherapeuticprogrammes;

4) supporting the activities of institutions, associations and individuals to solve alcohol problems;
5) supporting social employment by organising and financing social integration centres(Act of 26 October 1982, 1982, art. $4^{1}$ ).

The revenue of the municipalities from the fee for the permit to sell alcoholic beverages is spent on various social purposes. One of the key objectives financed in Poland from the fee permitting the sale of alcoholic beverages, is to prevent domestic violence resulting from the consumption of alcoholic beverages. The income from the fee is spent by municipalities on various activities, such as: Social Integration Centres, functioning of helplines, support groups, etc. Therefore, it should be stated that the financial resources obtained by municipalities from the levy in question enable the local communities to implement many activities which make it possible to reduce alcohol consumption and counteract the negative effects of alcohol consumption.

The assessment of the revenue from the fee for using the permit to sell alcoholic beverages is the subject of research by many scientists, who analyse the level of revenue to municipal budgets as well as expenditure in this area. For example, the issue discussed in the above publication was analysed by Izabela Nawrolska (Nawrolska, 2017, pp. 291-307). The author of the publication focused on the presentation of income from the charge on alcohol sales as the basic source of financing for counteracting the negative effects of alcohol consumption. The publication presents the revenue and expenditure from the alcohol sale levy with reference to all levels of local government. However, the current legal solutions have assigned the biggest tasks in this respect to local governments. Therefore, the examination of the level of income to the municipal budgets is a very important issue which requires analysis. In her publication, the author presented interesting conclusions concerning the effectiveness of spending the funds obtained from the charge in question. The author's conclusions even testify to the fact that the actions taken by municipalities in the field of combating excessive alcohol consumption are not effective. This means that spending the money from the alcohol sales levy is an interesting research challenge in the area of public finance and social policy.However, contrary to the example given, the charge from the alcohol marketing licence should be analysed separately in terms of income and expenditure, as this allows for a precise assessment of the area under examination.

Moreover, as Izabela Nawrolska has proved in her publication, it is the municipality that allocates the most funds to prevention against excessive alcohol consumption. I therefore believe that a separate inclusion of revenue in the budgets of local authorities is the right appro- 
ach. I also believe that the presentation of revenue from the fee in general without presenting an analysis based on the examples of specific local authorities does not make it possible to demonstrate the specific nature of the local issue in question, especially in the context of tourist municipalities.

\section{ConClusion}

Revenues from fees in the case of 13 selected communes of Pomorskie Voivodeship ( 8 urban and 5 rural) in Poland accounted for a small share of total revenue to the budget of individual communes in 2016-2019.

Analysis of the communes' income from the fee for using the permit to sell alcoholic beverages enabled the achievement of the assumed research objectives. Revenue from the fees in the case of 13 selected communes of Pomorskie Voivodeship ( 8 urban and 5 rural) in Poland comprised in 2016-2019 a small share in the total income to the budget of individual municipalities. They amounted to no more than $1.60 \%$ of the total income of municipalities. In the case of some communes, their share in total income even showed a downward trend, which may indicate a decreasing number of retail outlets or lower consumption of these goods. This information may raise some doubts because, according to the World Health Organisation, the consumption of alcoholic beverages is growing in Poland. Such a situation may potentially indicate an increase in sales outside the outlets which hold permits to sell alcoholic beverages. In addition, it may also mean that entrepreneurs may understate the actual revenue from the sale of alcoholic beverages in their annual statements submitted to the municipalities. The verification of the nominal amount of the communes' revenue from the fee charged to entrepreneurs for the permit to sell alcoholic beverages indicates that the year-on-year increase in revenue in individual years 2016-2019 occur- red only in 4 communes ( 2 urban - Gdańsk, Gdynia and 2 rural - Krokowa, Stegna). The remaining communes noted a variable trend in this respect. Such a situation may in practice hinder the process of planning the income to the budget of a given commune for the following year from the permit in question. Moreover, the lack of possibility to accurately assess the trend in revenue from the fee for selling alcoholic beverages may also hinder the implementation of the strategies adopted by the communes to solve alcohol problems caused by excessive consumption. It should be borne in mind that social programmes implemented in this respect are financed mainly from the funds obtained from the levy. The last issue covered by the analysis was the verification of the dynamics of communal income from the fee in individual years 2017-2019 in relation to the base year 2016. The results of this analysis showed that only one municipality of Smołdzino has recorded an annual decrease in revenue from the fee in 2017 -2019 compared to the revenue from 2016. This shows a certain trend in the level of revenue of the municipality of Smołdzino from this fee, which is confirmed by data on changes in nominal revenue in 2016-2019 on an annual basis.

In conclusion, it should be stated that the conducted analysis indicates the possibility of its deepening in various areas, if only by extending the research to include more local government units in Poland. The examined area, apart from the financial aspect, concerns very important social and management areas related to the functioning of local authorities in Poland. The decision-makers in communes deal with many issues for the inhabitants, apart from stimulating economic development, they should also take care of the social development of the inhabitants by counteracting the effects of addictions and abuses. Excessive alcohol consumption by a given community has a negative impact on the inhabitants of a given community and its image.

\section{REFERENCES}

Ataguba, J.E., Galindo, L.M., Shield, K.D., Sornpaisarn, B., Rehm, J. (2017). The Need for Alcohol Taxation and Pricing Policies. In:Österberg E., Rehm J., Shield K.D., Sornpaisarn B., Resource Tool on Alcohol Taxation and Pricing Policies, World Health Organisation, The Center for Alcohol Studies (CAS), Thailand.

Bahl, R., Linn, J. (1992).Urban Public Finance in Developing Countries. New York: Oxford University Press, The World Bank, Washington. Retrieved from:

http://documents.worldbank.org/curated/en/963911468739534803/pdf/multi-page.pdf.

Bird, R.M. (2010). Subnational Taxation in Developing Countries: A Review of the Literature. Policy Research Working Paper. Washington DC: The World Bank.

Èapková, S. (1997). Local Goverment Issues. In: Nemec J., Wright G. (Eds.).Public Finance: Theory and Practice in the Central european transition. The Network of Institutes and Schools of Public Administration in Central andEastern Europe, Bratislava (pp. 418-447). 
Freire, M.E., Garzón, H. (2014). Managing Local Revenues. In: Farvacque-Vitkovic C., Kopanyi, M. (Eds.). Municipal Finances. A Handbook for Local Governments (pp. 147-213), Washington DC: International Bank for Reconstruction and Development, The World Bank.

Glumińska-Pawlic, J. (2010). Opłaty za korzystanie z zezwolenia na sprzedaż napojów alkoholowych (Fees for the use of a permit to sell alcoholic beverages). In: Liszewski G. (Ed.), Opłaty samorzqdowe w Polsce - problemy praktyczne (Local government charges in Poland - practical problems), Temida 2, Białystok.

Gruber, J. (2016).Public Finance and Public Policy. Fifth edition, New York: Worth Publishers.

Łukomska, J., Neneman, J. (2018). Local Taxes and Fees as A Source of Revenue for Polish Municipalities: Substitutes or Complements?,Financial Internet Quarterly e-Finanse, 14(3) (pp. 49-59). Retrieved from:

https://finquarterly.com/archives/?number=58\&id=413

Łukowska, K. (2018). Rozwiązywanie problemów alkoholowych oraz ograniczanie dostępności alkoholu w gminach i miastach. Przewodnikdlasamorządowców (Solving alcohol problems and reducing alcohol availability in municipalities and cities. A guide for local governments), Mazovian Centre of Social Policy, Warsaw. Retrieved from:

http://mcps.com.pl/wp-content/uploads/2019/02/mcps-lukowska.pdf

Moeller, R.R. (2011). COSO Enterprise Risk Management. Establishing Effective Governance, Risk, and Compliance Processes. Second Edition. New Jersey: John Wiley \& Sons, Inc., Hoboken.

Nawrolska, I. (2017).Opłata za wydaniezezwolenianasprzedażalkoholujakoźródłofinansowaniaprofilaktykialkoholizmu (The fee for issuing a permit to sell alcoholas a source of funding for the preventionof alcoholism). Research papers of Wrocław University of Economics, no. 485, 291-307.

Wołowiec, T. (2013). Multiannual Financial Perspectiveas a Tool of Local Government Unit Development. Financial Internet Quarterly e-Finanse, 9(3), 72-82.

Retrieved from:

https://finquarterly.com/archives/?number=34\&id=97

Stiglitz, J.E., Rosengard, J.K. (2015).Economics of the Public Sector (4rd ed.). New York: London: W. W. Norton Company.

Tresch, R.W. (2015). Public Finance. A Normative Theory. Third Edition. San Diego: Elsevier Inc.

Evidence for the Effectiveness and Cost-effectiveness of Interventions to Reduce Alcohol-related Harm (2009). World Health Organisation, WHO Regional Office for Europe, Copenhagen $\varnothing$, Denmark. Retrieved from: https://www.euro.who.int/_data/assets/pdf_file/0020/43319/E92823.pdf

Florida Department of Revenue, Sales and Use Tax on Alcoholic Beverages.Retrieved from: https://floridarevenue.com/ Forms_library/current/gt800046.pdf

Guide for Tax Assessor Collectors February 2019, Texas Alcoholic BeveragesCommission.Retrieved from:https:// www.tabc.state.tx.us/publications/licensing/TAC.pdf

Tennessee Alcoholic Beverages and Beer Tax Guide (2019).Tennessee Department of Revenue.Retrieved from: https://www.tn.gov/content/dam/tn/revenue/documents/taxguides/alcbevguide.pdf

Status report on alcohol consumption, harm and policy responses in 30 European countries - 2019, (2019). World Health Organisation,WHO Regional Office for Europe, Copenhagen $\varnothing$, Denmark. Retrieved from:https://www.euro.who.int/ __data/assets/pdf_file/0019/411418/Alcohol-consumption-harm-policy-responses-30-European-countries-2019.pdf

Act of 26 October 1982 on Education in Sobriety and Counteracting Alcoholism (i.e. Journal of Laws of 2019, item 2277). Ustawa z dnia 26 października 1982 r. o wychowaniu w trzeźwości i przeciwdziałaniu alkoholizmowi (Dz. U. z 2019 r. poz. 2277).

Act of 8 March 1990 on municipal self-government (i.e. Journal of Laws of 2020, item 713).Ustawa z dnia z dnia 8 marca 1990 r. o samorządziegminnym (tj. Dz. U. z 2020, poz. 713). 
Act of 13 November 2003 on the income of local government units (i.e. Journal of Laws of 2020, item 23).Ustawa z dnia 13

listopada 2003 r. o dochodachjednosteksamorząduterytorialnego (D.U. z 2020 r., t.j. z 2020 r. poz. 23).

Report on the implementation of the Gdańsk budget for 2016-2019. Retrieved from:

https://bip.gdansk.pl/urzad-miejski/sprawozdanie-z-wykonania-budzetu-miasta-gdanska-za-2016-rok,a,74276 https://bip.gdansk.pl/urzad-miejski/sprawozdanie-z-wykonania-budzetu-miasta-gdanska-za-2017-rok,a,105365 https://bip.gdansk.pl/urzad-miejski/sprawozdanie-z-wykonania-budzetu-miasta-gdanska-za-2018-rok,a,142390 https://bip.gdansk.pl/urzad-miejski/sprawozdanie-z-wykonania-budzetu-miasta-gdanska-za-2019-rok,a,167822 Report on the implementation of the Gdynia budget for 2016-2019. Retrieved from:

https://bip.um.gdynia.pl/2016,336/sprawozdanie-z-wykonania-budzetu-miasta-gdyni-za-2016-rok,482556 https://bip.um.gdynia.pl/2017-3,6283/sprawozdanie-z-wykonania-budzetu-miasta-gdyni-za-2017-rok,519667 https://bip.um.gdynia.pl/2018-2,7389/sprawozdanie-z-wykonania-budzetu-miasta-gdyni-za-2018-rok,535901 https://bip.um.gdynia.pl/2019,7972/sprawozdanie-z-wykonania-budzetu-miasta-gdyni-za-2019-rok,548196 Report on the implementation of Jastarnia's budget for 2016-2019. Retrieved from:

http://bip.jastarnia.pl/dokumenty/4913

http://bip.jastarnia.pl/dokumenty/5508

http://bip.jastarnia.pl/dokumenty/6401

http://bip.jastarnia.pl/dokumenty/7266

Report on the implementation of the Łeba budget for 2016-2019. Retrieved from:

https://prawomiejscowe.pl/GminaMiejskaLeba/document/616721/Zarz\%C4\%85dzenie-38_2020

https://prawomiejscowe.pl/GminaMiejskaLeba/document/543727/Zarz\%C4\%85dzenie-45_2019

https://prawomiejscowe.pl/GminaMiejskaLeba/document/482486/Zarz\%C4\%85dzenie-56_2018

https://prawomiejscowe.pl/GminaMiejskaLeba/document/405097/Uchwa\%C5\%82a-XXIX_348_2017

Report on the implementation of the Krokowa commune budget for the years 2016-2019.Retrieved from:

http://bip.krokowa.pl/dokumenty/3961

http://bip.krokowa.pl/dokumenty/3978

http://bip.krokowa.pl/dokumenty/4729

http://bip.krokowa.pl/dokumenty/5456

Report on the implementation of the Puck City budget for 2016-2019. Retrieved from:

http://bip.miastopuck.pl/dokumenty/3195

http://bip.miastopuck.pl/dokumenty/4237

http://bip.miastopuck.pl/dokumenty/5259

http://bip.miastopuck.pl/dokumenty/6029

Report on the implementation of the Puck commune budget for 2016-2019.Retrieved from:

http://bip.gmina.puck.pl/dokumenty/4405

http://bip.gmina.puck.pl/dokumenty/3268

http://bip.gmina.puck.pl/dokumenty/2311

http://bip.gmina.puck.pl/dokumenty/1537

Report on the implementation of the Sopot budget for 2016-2019.Retrieved from:

https://www.bip.sopot.pl/a,17340,budzet-sopotu-2016.html

https://www.bip.sopot.pl/a,17755,budzet-sopotu-2017.html

https://www.bip.sopot.pl/a,18346,budzet-sopotu-2018.html

https://www.bip.sopot.pl/a,18881,budzet-sopotu-2019.html 
Report on the implementation of the Stegna Municipality budget for 2016-2019.Retrieved from:

http://bip.stegna.pl/system/obj/2343_51_2017._Zarzadzenie.WYKONANIE_ZA_2016_do_wyslania.Kopia.pdf

http://bip.stegna.pl/system/obj/4562_49_2018_Zarzadzenie.WYKONANIE_ZA_2017.pdf

http://bip.stegna.pl/system/obj/7187_50_2019_Zarzadzenie_Sprawozdanie_opisowe.pdf

http://bip.stegna.pl/system/obj/8062_50_2020_zarz..pdf

Report on the implementation of the Smołdzino Municipality budget for 2016-2019.Retrieved from: http://bip.smoldzino.com.pl/dokumenty/7905

http://bip.smoldzino.com.pl/dokumenty/7484

http://bip.smoldzino.com.pl/dokumenty/6735

http://bip.smoldzino.com.pl/dokumenty/5965

Report on the implementation of the City of Ustka budget for 2016-2019. Retrieved from:

https://bip.um.ustka.pl/a,28484,iv-kwartal-2019.html

https://bip.um.ustka.pl/a,27349,iv-kwartal-2018-rok.html

https://bip.um.ustka.pl/a,26411,iv-kwartal-2017-rok.html

https://bip.um.ustka.pl/a,24903,iv-kwartal-2016-rok.html

Report on the implementation of the Ustka commune budget for the years 2016-2019.Retrieved from:

http://bip.ustka.ug.gov.pl/a,24111,sprawozdania-budzetowe-za-iv-kwartal-2016.html

http://bip.ustka.ug.gov.pl/a,24780,zarzadzenie-nr-00505242018-wojta-gminy-ustka-z-dnia-26-marca-2018-roku-w-

sprawie-przedstawienia-spra.html

http://bip.ustka.ug.gov.pl/a,26038,zarzadzenie-nr-0050712019-wojta-gminy-ustka-z-dnia-20-marca-2019-roku-w-

sprawie-przedstawienia-spraw.html

Report on the implementation of the Władysławowo City budget for 2016-2019.Retrieved from:

https://bip.wladyslawowo.pl/a,22492,rb-27s-sprawozdanie-z-wykonania-planu-dochodow-budzetowych-jednostkisamorzadu-terytorialnego-okres-.html

https://bip.wladyslawowo.pl/a,24250,rb-27s-sprawozdanie-z-wykonania-planu-dochodow-budzetowych-jednostkisamorzadu-terytorialnego-okres-.html

https://bip.wladyslawowo.pl/a,25915,rb-27s-sprawozdanie-z-wykonania-planu-dochodow-budzetowych-jednostkisamorzadu-terytorialnego-od-poc.html

https://bip.wladyslawowo.pl/a,27289,rb-27s-sprawozdanie-z-wykonania-planu-dochodow-budzetowych-jednostkisamorzadu-terytorialnego-od-poc.html

http://bip.ustka.ug.gov.pl/a,27137,sprawozdania-za-iv-kwartal.html 